\title{
Analysis Factors of Using Internet Banking in Indonesia
}

\author{
Esi Oktafian Fatimah ${ }^{1, *}$ \& AMA Suyanto \\ ${ }^{1}$ School of Economics and Business, Telkom University, Indonesia \\ *Correspondence: School of Economics and Business, Telkom University, Indonesia. E-mail: \\ esioktafian@ymail.com
}

Received: February 11, 2016

Accepted: March 18, 2016 Online Published: April 19, 2016

doi:10.5430/mos.v3n2p10

URL: http://dx.doi.org/10.5430/mos.v3n2p10

\begin{abstract}
The success of internet banking depends on how the customer understanding the system. It is important for the bank to find out how consumers appreciate internet banking services in order to help find a strategic plan and increase market share. This study aims to determine the factors that influence the use of internet banking services.

The research used descriptive method. Data collection is done by distributing questionnaires to users of internet banking in Indonesia with a sample of 385 people with nonprobability sampling purposive. The analysis technique used is Exploratory Factor Analysis.

This research analyzes the 5 factors that exist are: Performance Expectancy, Facilitating Conditions, Social Influence, Trust, and Effort Expectancy. The results showed that there are three factors that influence the decision to use internet banking. Factors newly created change indicator with the addition or reduction in the number of indicators derived from different variables. The new three factors are: Performance Expectancy, Trust and Social Influence. Implication of this study will help the bank to improve its service quality so that the customers more comfortable and confident with the Internet banking service in Indonesia.
\end{abstract}

Keywords: internet banking; performance expectancy; social influence; trust

\section{Introduction}

The technology has been advanced so much far until now, 2015. This could be proved by much more Innovations now. The advanced of technology is important for supporting human's life.The using of internet, made a new phenomenon which is online channel. Lot of people use online site for doing something they need. Online channel trusted could be save times, cost, and effort (Warayuanti and Suyanto, 2015). Internet on bank industry is used for developing services to customers. It happened because internet is an innovation that could be given an easy for the users. Internet banking is one of many result from developing services by bank based on internet technology.

Internet banking has become one of the self-service that allows the bank to provide information and offer services to customers with more convenience through technology sophistication (Nisa et al., 2013). Internet banking is often also known as electronic banking (e-banking), Cyberbanking, Virtual Banking, Home Banking and Online Banking. Internet banking is the banking activities conducted from home, office, or other places by using the internet. Internet banking is a concern and the main strategic weapon banks, both for services to customers as well as for competition among banks (Nurastuti, 2011: 113).

Internet banking services provided by the bank with the main objective to provide convenience to customers. Banking services via the Internet in the form of a certain bank websites that provide direct services without the need to come to the bank concerned. It is easier for customers to do banking activities as they can access the site and use the features in it such as balance checking, transaction history, transfer, bill payments, purchase vouchers to the tickets, and various other features provided, wherever and whenever for internet access. Another convenience is the site is similar with another general site, so that customers can access directly (Hambali et al., 2011).

High users and the benefits by using Internet banking is interesting to do a research to analyze the factors that influence the use of internet banking in Indonesia. This is important because the result from this research can provide guidance for the banking industry in order to formulate their strategy, maintain consistency and excellence in the era of 
competition today.

\section{Literature Review}

\subsection{Marketing}

Marketing is a social and managerial process in which individuals and organizations can obtain what they need and want through creating and exchanging value. Whereas in the context of the business, including establishing marketing benefits and value exchange relationship with the consumer. So marketing as the process by which Companies create value for customers and build strong relationships with consumers in return to get value from customers (Kotler and Armstrong, 2014: 27).

\subsection{Service}

According to Kotler and Armstrong (2014: 248), the service is a form of products which consists of activities, benefits or satisfaction offered for sale that are essentially intangible and does not result in any ownership. The examples include banking services, hotels, airlines, retail, communications, and home repair services. There are several characteristics of the service according to Tjiptono and Chandra (2011:35-41) as follows:

\section{Intangibility}

Services is different from goods. Services can not be seen, felt, smell, heard, or touched before being bought and consumed.

\section{Heterogeneity / Variability / Inconsistency}

Services are highly variable because it is a non-standardized output, it mean that there are many variations of shape, quality, and types, depending on who, when, and where the services are produced.

\section{Inseparability}

Services generally sold first, then produced and consumed within the same time and place.

4. Perishability

Services are perishable commodities, can not be saved for reuse in future, resold, or returned.

\subsection{Consumer Behavior}

American Marketing Association defines the behavior of consumers as a dynamic interaction between influence and awareness, behavior, and environment where is humans exchange aspects of life. In other words, consumer behavior involves their thoughts and feelings and what they are doing in the process of consumption (Peter and Olson, 2014: 6).

\subsection{Purchase Decision}

Purchase decision is a decision-making process about purchase that includes determining what to buy or not and the decision was obtained from previous activities (Siburian et al., 2013). While purchasing decisions in the use of the service is called with the use decision. Decision to use the service is part of consumer behavior, the general consumer behavior is the activities of individuals who are directly involved in obtaining and using goods and services, including the decision-making process on the preparation and determination of these activities (Siburian et al., 2013).

\subsection{Self-Service Technology (SST)}

Self-Service Technology (SST) is a technology that allows customers to generate their own services that they need without relying on employees. As an example of SST namely Automated Teller Machines (ATMs), mobile banking, and internet banking. SST changing the way customers interact with the company to create the required services (Meuter et al., 2000).

\subsection{Internet}

Internet is short for Interconnected Network. The Internet is a communication system that is capable of linking computer networks around the world. The Internet is a global network that connects people and information, has opened up enormous possibilities for the advancement of research and expand business opportunities around the world (Sekaran, 2011: 55). Internet provides many advantages and disadvantages for the users. The advantage is the ease of getting information and the latest news, support access to transactions and business operations, purchase online, distance learning system (e-learning), communication, job search, and transfer money (banking). While the disadvantage of Internet is the ease of plagiarism, online crime, piracy, etc. (Nurastuti, 2011: 114). 


\subsection{Internet Banking}

According to Bank Indonesia (Nurastuti, 2011: 112), internet banking is one of bank services that enable customers to obtain information, communicate and made banking transactions through the Internet. Internet banking activity can be divided into three types, informational internet banking, communicative internet banking and transactional internet banking. Informational Internet banking is bank services to customers that give an information through the Internet and not to execute the transaction. Communicative Internet banking is the bank services to customers that give customer an ability to communicate or interact with the bank as providers of internet banking service in limited way and does not execute the transaction. Transactional internet banking is bank services to customers to interact with provider's bank service and internet banking, and allowed to execute transaction.

\subsection{Framework}

Performance Expectancy (PE) refers to the degree that people believe using internet banking could help them make a profit or save money while doing online banking tasks (Venkatesh et al., 2003).

Facilitating Conditions (FC) refers to the impact of technical and organizational infrastructure to support the use of online banking that contains the user's ability, knowledge, and resources (Venkatesh et al., 2003).

Social Influence (SI). Definition of social influence as perceived someone to use new technologies that are influenced by others whom he believed. This factor reflects the influence of variables such as the opinion of family, close friends, and co-users (Venkatesh et al., 2003).

Trust. During the last years, the important role of starting, building, and maintaining trust between sellers and buyers online platform is recognized for the success of electronic commerce. One of the most important reasons why trust became the most important variable when conducting online transactions is the level of uncertainty that exists in a virtual environment that is perceived by consumers (Zahir and Gharleghi, 2015).

Effort Expectancy (EE) shows the level ease of use for online banking and it is equivalent to the perceived ease of use on some other models using the same construction (Al-Qeisi 2009; Zahir and Gharleghi, 2015).

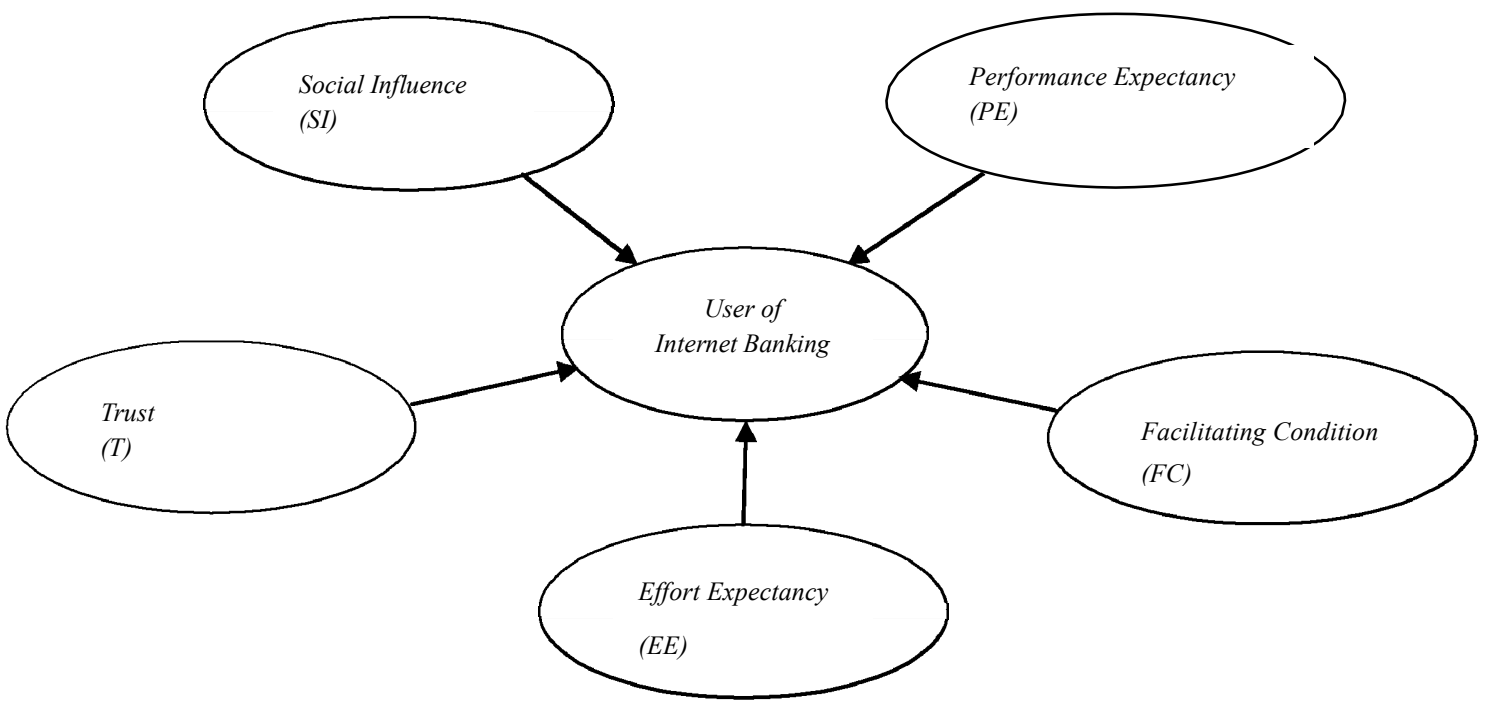

Figure 1. Framework Research

Source: Data that have been processed

\subsection{Methodology}

The method has been used is descriptive research. Data collection is done by distributing questionnaires to users of internet banking Indonesia with a sample of 385 people by nonprobability purposive sampling method. The analysis technique used exploratory factor analysis.

\section{Discussion}

In this study, using the number of respondents 385 people which is an internet banking users in Indonesia. In Table 
1 below are the characteristics of respondents by banks are used, sex, age, job, income and region.

Table 1. Characteristics of Respondents

\begin{tabular}{|c|c|c|c|}
\hline \multicolumn{2}{|r|}{ Characteristics Respondents } & \multirow{2}{*}{$\begin{array}{c}\text { Sum } \\
108\end{array}$} & \multirow{2}{*}{$\frac{\text { Percentage }}{29 \%}$} \\
\hline & $\mathrm{A}$ & & \\
\hline & $\mathrm{B}$ & 70 & $18 \%$ \\
\hline & $\mathrm{C}$ & 65 & $17 \%$ \\
\hline \multirow[t]{24}{*}{ Bank* } & $\mathrm{D}$ & 117 & $31 \%$ \\
\hline & $\mathrm{E}$ & 15 & $4 \%$ \\
\hline & Others & 10 & $1 \%$ \\
\hline & Male & 18 & 47 \\
\hline & Female & 20 & 53 \\
\hline & $\leq 19$ y.o & 9 & $2 \%$ \\
\hline & $19-25$ y.o & 16 & 33 \\
\hline & $26-32$ y.o & 14 & 31 \\
\hline & $33-39$ y.o & 51 & 13 \\
\hline & $\geq 40$ y.o & 18 & $5 \%$ \\
\hline & Student & 8 & $2 \%$ \\
\hline & Collage & 92 & 24 \\
\hline & Employee & 12 & 33 \\
\hline & Entrepreneur & 11 & 31 \\
\hline & Teacher & 33 & $9 \%$ \\
\hline & Others & 6 & $1 \%$ \\
\hline & $<$ Rp. 500.000 & 28 & $7 \%$ \\
\hline & Rp. 500.001 - Rp. 2.500 .000 & 18 & 49 \\
\hline & Rp. $2.500 .001-$ Rp. 4.500 .000 & 92 & 24 \\
\hline & Rp. $4.500 .001-$ Rp. 6.500 .000 & 45 & 12 \\
\hline & $\geq$ Rp. 6.500 .001 & 31 & $8 \%$ \\
\hline & West of Indonesia & 35 & 93 \\
\hline & Center of Indonesia & 19 & $5 \%$ \\
\hline & East of Indonesia & 9 & $2 \%$ \\
\hline
\end{tabular}

Source: Data been processed *) Name of Bank are Hide

Based on these data shows that mostly Female 53\% are using internet banking on 2 Big Banks (both Public and Private Banking). The interested users are dominated by young people $64 \%$ between 19 to 32 years old. In term of job, $33 \%$ are Employee and 31\% Entrepreneur. The internet Banking user also dominated by people who live at West of Indonesia.

Testing of factor analysis in this study using IBM SPSS Statistics 20 software which analyzes five variables: Performance Expectancy, Facilitating Conditions, Social Influence, Trust, and Effort Expectancy by using 18 indicators. After testing is obtained the following results:

Table 2. Descriptive Statistics

\begin{tabular}{cccc}
\hline & Mean & Std. Deviation & Analysis N \\
\hline PE1 & 8,06 & 2,093 & 385 \\
PE2 & 8,10 & 2,003 & 385 \\
PE3 & 6,99 & 2,296 & 385 \\
PE4 & 7,86 & 2,120 & 385 \\
FC1 & 8,19 & 2,066 & 385 \\
FC2 & 8,34 & 1,982 & 385 \\
SI1 & 6,58 & 2,528 & 385 \\
\hline
\end{tabular}




\begin{tabular}{cccc}
\cline { 2 - 3 } SI2 & 7,38 & 2,180 & 385 \\
SI3 & 5,95 & 2,527 & 385 \\
T1 & 7,14 & 2,098 & 385 \\
T2 & 6,96 & 2,072 & 385 \\
T3 & 6,99 & 2,084 & 385 \\
T4 & 6,88 & 2,052 & 385 \\
T5 & 6,56 & 2,301 & 385 \\
EE1 & 7,45 & 2,165 & 385 \\
EE2 & 7,34 & 2,060 & 385 \\
EE3 & 7,65 & 2,000 & 385 \\
EE4 & 7,50 & 2,048 & 385 \\
\hline
\end{tabular}

Source: Data been processed

Descriptive analysis gives an overview of the data held. In describing the data, can use a variety ways. In the factor analysis, descriptive analysis overview is given by the average (mean) and standard deviation of each variable (Simamora, 2005: 122).

Based on the results of the factor analysis obtained three new factors that formed the new indicators. Grouping is done based on the value factor loading. Here are three factors are newly formed.

Table 3. The New Factor Components

\begin{tabular}{llll}
\hline Faktor & $\begin{array}{l}\text { No. } \\
\text { Item }\end{array}$ & Item & $\begin{array}{l}\text { Factor } \\
\text { Loading }\end{array}$ \\
\hline 1 & PE1 & Internet banking allows me to perform banking transactions to be faster & 0,868 \\
& PE2 & Internet banking allows to use my time more effectively and efficiently & 0,881 \\
& PE3 & Internet banking allows me to manage my finances more effectively & 0,511 \\
& PE4 & Internet banking is so useful for me & 0,781 \\
& FC1 & Advances in internet technology supports me in using internet banking & 0,840 \\
& FC2 & Speed of internet access is very important when using internet banking & 0,838 \\
SI2 & I prefer to use internet banking instead of doing transact with a bank employee at & 0,544 \\
& & the bank & \\
& EE3 & Easy for me to learn how to do available transaction on my internet banking & 0,769 \\
& & websites & \\
& EE4 & I feel confidence using internet banking for transaction & 0,642 \\
T1 & I trust in using technology of internet banking & 0,705 \\
& T2 & I believe that internet banking will protect my privacy & 0,817 \\
T3 & I trust internet banking just as I trust bank & 0,835 \\
& T4 & Using internet banking is financially secure & 0,824 \\
T5 & I am not worry about secure from internet banking that I have used & 0,848 \\
& EE1 & Open the website of internet banking does not need much effort & 0,608 \\
EE2 & Websites of internet banking has a clear procedure that easy to understand & 0,611 \\
& SI1 & I got suggest to use internet banking from others (family, friends, partner) & 0,855 \\
SI3 & I got suggest from people around me (family, friends, partner) to use internet for & 0,813 \\
& doing banking transaction & \\
\hline
\end{tabular}

Source: Data been processed

The next process to be conducted in this study is naming a new factor which is formed by sort factor loading of each variable from the largest number to the smallest in each component. The establishment of name made subjectively by the author using the biggest factor loading in a component that is used as name of the new factor. Here are names of new factors that just formed. 
Table 4. New Factor

\begin{tabular}{clc}
\hline Factor & \multicolumn{1}{c}{ New Factor } & Contribution \\
\hline 1 & Performance Expectancy & $65,858 \%$ \\
2 & Trust & $7,554 \%$ \\
3 & Social Influence & $6,158 \%$ \\
Total & & $79,570 \%$ \\
\hline
\end{tabular}

Source: Data been processed

These three new factors that can explain $79.570 \%$ of the variability of the five variables studied and can not explain the variability of $20.430 \%$ because it does not contribute significantly to the variables studied.

\section{Conclusions}

From the analysis and processing data it can be concluded as follows:

1. Characteristics of respondents include banks are used, sex, age, job, income and domicile, it is known that internet banking users $60 \%$ are customers of 2 Big Banks, $53 \%$ are female clients, $79 \%$ are users aged $19-32$ year, $64 \%$ are users who have a job as an employee and self-employed, $73 \%$ are users who have an average monthly income of Rp. 500,000 - Rp. 4,500,000 and 93\% are users who live in western Indonesia.

2. There are three factors that influence the decision to use internet banking. Factors newly created had change its indicator with the addition or reduction from different variables. The new three factors are: Performance Expectancy, Trust and Social Influence

3. The most dominant variable of each factor is the "Internet banking allows to use my time more effectively and efficiently" factors contained in the Performance Expectancy, "I am not worry about secure from internet banking that I have used" contained in the Trust factor and "I got suggest to use internet banking from others (family, friends, partner)" contained in the Social Influence factor.

\section{References}

Hambali, F., Akhirson, A., dan Wijayanti, R. (2011). Analisis Technology Acceptance Model (TAM) Terhadap Faktor-Faktor yang Mempengaruhi Penerimaan Nasabah Terhadap Layanan Internet Banking (Studi Empiris Terhadap Nasabah Bank di Depok). Proceeding PESAT, 4, 121-127.

Kotler, P. dan Armstrong, G. (2014). Principles of Marketing (15 ${ }^{\text {th }}$ ed.). England: Pearson.

Menggunakan Layanan. (2013). Internet Banking Mandiri. Jurnal Manajemen, 13(1).

Meuter, M. L., Ostrom, A. I., Roundtree, R. I., \& dan Bitner, M. Jo. (2000). Self-Service Technologies: Understanding Customer Satisfaction with Technology-Based Service Encounters. Journal of Marketing, 64(3), 50-65.

Nisa, D. D., Ariyani, T. S., \& Oktaviani, K. (2013). Analisis Faktor-Faktor Yang Mempengaruhi Nasabah

Nurastuti, Wiji. (2011). Teknologi Perbankan. Yogyakarta: Graha Ilmu.

Peter, J. P., \& Olson, J. C. (2014). Perilaku Konsumen \& Strategi Pemasaran (9 $9^{\text {th }}$ ed.). Jakarta: Salemba Empat.

Sekaran, Uma. (2011). Research Methods For Business. Jakarta: Salemba Empat.

Siburian,T.M.P., Lubis, N., \& Susanto, H. (2013). Pengaruh Kualitas Pelayanan, Produk dan Harga Terhadap Keputusan Penggunaan Jasa Asuransi AJB Bumiputera 1912 Kantor Cabang Eksekutif Semarang. JIAB.

Simamora, Bilson. (2005). Analisis Multivariat Pemasaran. Jakarta: PT. Gramedia Pustaka Utama.

Tjiptono, F., \& Chandra, G. (2011). Service, Quality \& Satisfaction ( $3^{\text {th }}$ ed.). Yogyakarta: ANDI.

Venkatesh, V., Morris, M. G., Davis, G.B., \& Davis, F. D. (2003). User Acceptance of Information Technology: Toward a Unified View. MIS Quarterly, 27(3), 425-478.

Warayuanti, Wike \& Suyanto, A.M.A. (2015). The Influence of Lifestyles and Consumers Attitudes On Product Purchasing Decision Via Online Shopping In Indonesia. European Journal of Business and Management, 7(8), 74-80.

Zahir, M., \& dan Gharleghi, B. (2015). Adoption of Internet Banking in Maldives, the Most Important Determinants. Asian Social Science, 11(2), 181-189. 